\title{
Impact of physical therapy on the condition of a patient with carpal tunnel syndrome and Raynaud's disease
}

\author{
Wpływ fizykoterapii na stan pacjentki z zespołem cieśni nadgarstka \\ i chorobą Raynauda
}

\author{
Ewelina Kobryńska ${ }^{1, A-D, F \oplus}$, Anna Zalewska ${ }^{2, A, D-F} \oplus$, Monika Gałczyk ${ }^{2, E} \oplus$, Arkadiusz Komorowski ${ }^{3, E-F} \oplus$ \\ ${ }^{1}$ Higher School of Rehabilitation, Warsaw, Poland \\ ${ }^{2}$ Lomza State University of Applied Sciences, Łomża, Poland \\ ${ }^{3}$ Eleonora Reicher National Institute of Geriatrics, Rheumatology and Rehabilitation, Warsaw, Poland \\ A - Research concept and design, B - Collection and/or assembly of data, C - Data analysis and interpretation, \\ $D$ - Writing the article, $E$ - Critical revision of the article, $F$ - Final approval of article
}

Kobryńska E, Zalewska A, Gałczyk M, Komorowski A. Impact of physical therapy on the condition of a patient with carpal tunnel syndrome and Raynaud's disease. Med Og Nauk Zdr. 2021; 27(1): 82-85. doi: 10.26444/monz/133956

\begin{abstract}
Introduction. Carpal tunnel syndrome (CTS) is the most common mononeuropathy that causes median nerve damage at the level of the carpal tunnel. Wrist overload associated with repeated fast movements, often requiring the forced position of the body which loads the wrist joints, is considered to be the most important cause in the formation of CTS. This disease significantly affects patients' manual skills and limits their daily activities. The use of the best treatment methods can increase the quality of life of CTS people. Correctly performed assessment of the patient's functional condition allows both the planning, implementation and improvement process, as well as control of the progress of this process. The treatment method for CTS depends on the type, duration and severity of the discomfort. Raynaud's syndrome is a vasomotor disorder which occurs mostly due to the influence of physicochemical or emotional stimuli. It is observed in 3-15\% of the general population, more often among women. The primary character is called Raynaud's disease, while the secondary is known as Raynaud's syndrome. Objective. The aim of the study was to investigate the effect of classical physical therapy on the condition of a patient with carpal tunnel syndrome and Raynaud's disease.
\end{abstract}

Materials and method. The method of an individual case description was used. The study involved a 36-year-old woman diagnosed with carpal tunnel syndrome and Raynaud's disease. The material was collected by means of an interview, DASH questionnaire, VAS pain scale and two functional tests: the Phanel and Tinnel tests. Description of the individual case study was based on an interview and physical examination performed before and after rehabilitation.

Results. Considering the subjective assessment of the achieved improvement after the treatment, the patient noticed a slight decrease in the intensity of pain and numbness, both during the day and at night. The respondent also reported a slight improvement in the function of the upper limbs and improved freedom during some everyday activities.

Conclusions. Physiotherapeutic procedures slightly reduced the numbness of both the day and night pain. Despite only

Address for correspondence: Anna Zalewska, State Higher School of Information Technology and Entrepreneurship, 18-400 Łomża, Poland

E-mail: aanna.zalewska@gmail.com

Received: 27.09.202; accepted: 01.03.2021; first published: 15.03.2021 a few treatments, the patient noticed a slight improvement which confirms that they were correctly selected and should be continued. During the next physiotherapeutic procedure, kinesitherapy should be introduced.

\section{Key words}

physiotherapy, improvement, carpal tunnel, Ranyaud's disease

\section{Streszczenie}

Wstęp. Zespół cieśni kanału nadgarstka (ZCKN) jest najczęściej występującą mononeuropatią związaną z uszkodzeniem nerwu pośrodkowego. Prawidłowo dokonana ocena funkcjonalnego stanu pacjenta pozwala odpowiednio zaplanować i zrealizować proces usprawniania oraz kontrolować jego postępy. Objaw Raynauda to zaburzenie naczynioruchowe, które występuje najczęściej pod wpływem bodźców fizykochemicznych lub emocjonalnych. Obserwuje się go u 3-15\% populacji ogólnej. Przy charakterze pierwotnym mówi się o chorobie Raynauda, przy wtórnym - o zespole Raynauda.

Cel pracy. Celem pracy było zbadanie wpływu klasycznej fizykoterapii na stan pacjenta z zespołem cieśni nadgarstka i chorobą Raynauda.

Materiał i metoda. Zastosowano metodę opisu przypadku indywidualnego. Badaniami objęto 36-letnią kobietę, u której zdiagnozowano zespół cieśni nadgarstka i chorobę Raynauda. Materiał zebrano za pomocą wywiadu, kwestionariusza DASH, skali bólu VAS oraz testów funkcjonalnych: Phanel i Tinnel.

Wyniki. Biorąc pod uwagę subiektywną ocenę uzyskanej po zabiegu poprawy, należy stwierdzić, że pacjentka zauważyła niewielkie zmniejszenie nasilenia bólu i drętwienia zarówno w dzień, jak i w nocy. Respondentka zgłosiła również niewielką poprawę funkcji kończyn górnych oraz poprawę swobody podczas niektórych codziennych czynności.

Wnioski. Zabiegi fizjoterapeutyczne w niewielkim stopniu zmniejszyły intensywność drętwienia oraz bólu dziennego i nocnego. Pomimo że zabiegów było niewiele, pacjentka zaobserwowała nieznaczną poprawę, co potwierdza, że zostały one dobrane prawidłowo i należy je kontynuować. W kolejnym postępowaniu fizjoterapeutycznym należy wprowadzić kinezyterapię.

\section{Słowa kluczowe}

fizykoterapia, zespół cieśni nadgarstka, choroba Raynauda 


\section{INTRODUCTION}

Carpal tunnel syndrome (CTS) is the most common mononeuropathy, which involves the median nerve damage at the level of the carpal tunnel $[1,2]$. CTS affects $1-2 \%$ of the general population and is observed three times more often in women than in men. Wrist overload associated with repeated fast movements, sometimes requiring the forced position of the body which loads the wrist joints, is considered to be the most important cause in its formation [3]. This disease significantly affects patients' manual skills and limits their daily activities. The use of the best treatment methods may increase the quality of life of CTS people [4].

The initial symptoms of CTS are usually short-termed and not very characteristic, and therefore ignored by patients. In this initial period, a transient tingling sensation or numbness occurs in the area that supplies the median nerve. The discomfort experienced may not only involve the hand itself. It often spreads to the forearm, elbow, arm or shoulder, and can also radiate to the neck. The later phase characterizes with hand pain at night, and numbness that also annoys during the day. This happens when performing activities requiring placing the wrist in a forced position, and during activities in which the movements of extending and bending the wrist are repeated many times. Sensory disturbances are also observed in the course of CTS. In a more advanced CTS period, some patients experience reduced muscular strength or atrophy of the thenar of the thumb, which results in impaired performance of precise movements $[1,5]$.

Correctly performed assessment of the patient's functional condition allows correct planning and implementation of the improvement process and monitoring the progress of this process [6]. In the case of CTS diagnostics, similarly to other disease entities, a well-conducted medical history and physical examination, as well as differential diagnosis, are particularly important [7]. Major diagnostic difficulties occur at the beginning of the CTS, when patients report typical complaints, but physical examination usually does not reveal objective hypoaesthesia in the area innervated by the median nerve. According to the Phalen definition, the CTS diagnosis can be made in a patient with one or more of the three main symptoms: positive Phalen symptom, positive Tinel symptom and sensory disturbances within the median nerve innervation [8].

The CTS treatment method depends on the type, duration and severity of the discomfort. The patient's attitude is also an important aspect. There isthea possibility of conservative and surgical treatment [9]. Physiotherapeutic procedures used in the treatment of CTS include mainly: laser therapy, ultrasound, iontophoresis, TENS, pulsed lowfrequency magnetic field, vortex bath of the upper limb, neuromobilization, PIR, passive stretching of the forearm flexors by the therapist with the patient's relaxed muscles, deepening of passive flexion in the wrist, stretching and massage. It is also important to treat a postoperative scar if the patient has undergone surgery. Due to the possibility ofoedema in the course of this disease, it is also possible to perform lymphatic drainage [10].

Raynaud's disease is a vasomotor disorder in which sudden and well-delineated paleness, bruising and redness of the fingers, toes, nose and auricles are observed. Pain and numbness are also noted. This disorder is mainly observed in young women. In a cool climate, the presence of the disorder is estimated at about $30 \%$ of the population. The etiology of the disease is unknown $[11,12]$.

The main assumptions of classic physiotherapy in a patient with carpal tunnel syndrome and Raynaud's disease are:

- reduction of pain and discomfort associated with numbness and tingling;

- improving the quality of life;

- prevention of muscular atrophy $[11,12]$.

The combination of carpal tunnel syndrome and Raynaud's disease is not common in clinical practice. The incidence of Raynaud's disease in patients with CTS is not well defined. There is a possible relation between Raynaud's syndrome in patients with CTS [13].

The reason for interest in the presented case was the unusual combination of similar symptoms regarding hand pain and numbness in the course of CTS and Raynaud's disease, which were the reasons to investigate the effect of classical physical therapy on the condition of the CTS and Raynaud's disease on the patient.

\section{MATERIALS AND METHOD}

The method of an individual case of a woman aged 36 years was used. The material was collected by means of:

- an interview which included 16 detailed questions regarding: age, profession, time elapsed since the diagnosis of CTS and Raynaud's disease, characteristic symptoms of CTS and Raynaud's disease, surgical treatment, use of rehabilitation methods, taking medication or injections administered to the carpal tunnel, use of wrist braces, and associated diseases;

- the DASH questionnaire, i.e. the questionnaire regarding the disability of the upper limb. The basic module contained 30 questions that concerned the performance of basic daily activities, sexual activity, traveling (moving), recreational activities, social activity, severity of illness symptoms (i.e. pain, tingling, stiffness, weakness of the hand), and sleep problems. Each question had 5 answers, ranging from "I didn't have any difficulty" to "I wasn't able to do it", and scored from 1-5. The scoring was then used to calculate the score on a scale of 0 (no disability) up to 100 (severe disability). The calculation of the DASH indicator was performed using a special formula;

- the vVAS pain rating scale, i.e. a visual analogue scale used to measure pain intensity. The simplest VAS scale was used for the study, i.e. the horizontal line, containing markings from 0 (no pain) to 10 (unbearable pain). The higher the score, the more intense the pain [26]. Assessment was made by the patient on the basis of subjective observations, separately for day and night pain;

- two functional tests:

- Phalen test, the patient performs maximal palmar flexion of the hands for 1 minute, the test checks the appearance or absence of paresthesia in the area of innervation by the median nerve.

- Tinnel test, which consisted of tapping the median nerve in the area of the carpal tunnel to check for the appearance or absence of pain, tingling, "passing current" sensation in the area innervated by the median nerve [2]. 
All of the above methods of assessing the patient's functional state were used twice: before the patient began rehabilitation and after completion of the two-week therapeutic sessions.

\section{CASE REPORT}

The case report concerns a right-handed woman, aged 36, diagnosed with carpal tunnel syndrome and Raynaud's disease. The patient worked as a waitress, but had to quit her job for health reasons. This decision was caused by growing problems with her hands, i.e. pain, stiffness and numbness. CTS in the patient was diagnosed a year ago and Raynaud's disease ten years ago. CTS surgical treatment was not implemented. The woman did not use orthopedic equipment. There was also no treatment due to the diagnosis of Raynaud's disease. The patient was receiving injections of non-steroidal anti-inflammatory drugs into the carpal tunnel, which she thought were unsuccessful. She did not take any other oral painkillers or physiotherapy. The subject had no other comorbidities.

During the first examination, the patient reported morning numbness, fingers' stiffness, and the feeling of swelling of the hands. She complained about similar symptoms during the night. She was often woken up by the night pain and forced to "flick off her hands" to reduce the symptoms. The woman did not complain of spontaneous daily pain, but only of pain after performing intensive daily activities, e.g. cleaning. Symptoms and weakness of the hand were observed with greater intensity on the right side. Symptoms resulting from Raynaud's disease appeared symmetrically on the fingers, mainly in situations of increased stress, and no more than twice a month.

Applied physical therapy programme. Physical therapy aimed at reducing the patient's pain, as well as eliminating oedema, improving the blood supply and reducing muscle tension in the hand. A series of three physical therapy treatments was ordered for the patient, which lasted for two weeks. During the rehabilitation, the patient was informed about the need to rest, or at least limit the activities that cause discomfort, not only during the therapeutic session, but also afterwards. The patient was also offered the use of a support orthotic to immobilize the wrist in an intermediate position at night. There were applied:

- Iontophoresis: this is a procedure involving the introduction of drug ions, and due to the strength of the electric field, undergoes electrolytic dissociation into the tissues. The main purpose of the treatment is anti-inflammatory activities. Implemented medication: $\mathrm{CaCl} 2$ (1-2\%). Current dose: $0.1 \mathrm{~mA} / \mathrm{cm} 2$. Duration of treatment: $15 \mathrm{~min}$. Performed five times a week.

- Ultrasound: this is the effect of an ultrasonic wave passing through the skin to deeper structures by means of thermal and mechanical actions. The main purpose of the treatment is an analgesic and anti-inflammatory action. Parameters used: power $-0.4 \mathrm{~W} / \mathrm{cm} 2$, frequency $-3 \mathrm{MHz}$, duration of treatment $-3 \mathrm{~min}$, performed five times a week.

- Sollux: a lamp using infrared radiation (IR) which causes expansion of the blood vessels, resulting in improved nutrient exchange, anti-inflammatory and analgesic effects. Duration of treatment - 15 min., performed five times a week.
Impact of rehabilitation on the patient's functioning according to the VAS scale, DASH questionnaire and provocation tests. Before the rehabilitation, the patient determined the value of the VAS scale for day pain on day seven, and for night pain on day six. After a two-week therapeutic session, day and night pain was rated at five.

During the first examination, the value of the DASH indicator was 28.33. After the rehabilitation, the rate was 14.16.

Results of provocative tests before the procedure were: positive Phalen and Tinel test for both right and left hand.

After completing rehabilitation, the Phalen and Tinel test results were positive for both hands.

Table 1. Comparison of all scales, indicators and provocation tests before and after patient's rehabilitation

\begin{tabular}{lcc}
\hline & $\begin{array}{c}\text { Prior to physiotherapeutic } \\
\text { procedures }\end{array}$ & $\begin{array}{c}\text { After physiotherapeutic } \\
\text { procedures }\end{array}$ \\
\hline VAS (day) & 7 & 5 \\
\hline VAS (night) & 6 & 5 \\
\hline DASH value & 28.33 & 14.16 \\
\hline Tinel test (right handa) & positive & positive \\
\hline Tinel test (left hand) & positive & positive \\
\hline Phalen test (right hand) & positive & positive \\
\hline Phalen (left hand) & positive & positive \\
\hline
\end{tabular}

Source: author's own study.

In the subjective assessment of improvement after the applied treatment, the patient noted a slight decrease in the intensity of pain and numbness both during the day and at night. The respondent also reported a slight improvement in the functioning of the upper limbs, and improved freedom during particular everyday activities. The woman noticed a slight improvement in the quality of life because of ailments decrease what facilitated the performance of daily activities, However, the improvement in the state of health did not occur in such a way to make it possible for the respondent to return to her profession. The patient did not notice a decrease in the frequency of Raynaud's disease.

\section{DISCUSSION}

The issue of rehabilitation of the carpal tunnel syndrome is often discussed in the literature $[14,15,16,17]$. The cause of carpal tunnel is very diverse with most cases being of idiopathic origin [18]. The origin of CTS in the patient in e presented study is unknown; however, the determining factor in this case could be the woman's work as a waitress during which she may have suffered local pressure in the wrist canal. An interview, VAS scale and two functional tests, the Phalen test and the Tinel test, were used to examine the patient. It is argued that an interview and physical examination are necessary for the initial diagnosis of carpal tunnel syndrome, as well as the usefulness of provocation tests, i.e the Tinel test, the Phalen test, and the Durkan test [19]. It is important to perform a thorough diagnosis and perform electrodiagnostics in addition to the interview and physical examinations. In order to confirm CTS, the whole examination should be completed by imaging, e.g. in the form of USG [20]. The woman under observation was 
administered a series of three physiotherapeutic treatments: Sollux lamp irradiation, ultrasound and iontophoresis. In the author's own research, the treatments offered to the patient brought little effect in the form of reducing pain and improving the patient's functioning. Dakowicz et al. compared the effectiveness of the pulsed magnetic field and the combined therapy consisting of laser biostimulation and a pulsed magnetic field. Due to observations, the greater effectiveness of the combined method was found which significantly reduced the feeling of subjective symptoms of the disease. In addition, it was noted that the treatment effect was maintained up to six months after the end of treatment [21]. Zwolińska and Kwolek assessed in their work the effectiveness of sonotherapy, whirlpool massage and median nerve neuromobilization. In their research they showed, inter alia, improved hand feeling in 20 out of 48 respondents and noted a significant improvement in the condition of the hands in the subjective assessment of patients, which related to their previous difficulties in self-service or pain, both during the day and at night [22]. According to Wilk the ailments of the patient decreased as a result of the application of lymphatic drainage and therapeutic massage. The effectiveness of the therapy in that case may, however, result not only from the physiotherapeutic treatment, as the patient under observation had previously undergone carpal tunnel treatment [23].

The DASH questionnaire and the VAS scale were used to compare the effects of physiotherapy in the studied patient. The same methods were used by Kocjan [24]. The authors' own research showed that after a two-week treatment session, the value of the DASH index decreased from 28.33 to 14.16 . The value of the VAS scale for daytime pain decreased from 7 to 5 , and was reduced from 6 to 5 in the case of night pain. Ciechanowska and Łukowicz also performed the Phalen, Tinel and Durkan tests. Before the procedures, an examination confirmed the presence of CTS, which gave characteristic symptoms in $95 \%$ of the examined patients. Following the therapy, the values did not change [25].

The combination of carpal tunnel syndrome and Raynaud's disease is not common in clinical practice, and the incidence of Raynaud's disease in patients with CTS is not well defined. There is a possible relationship between Raynaud's syndrome in patients with CTS [13]. It has been proven that patients with CTS and Raynaud's syndrome treated with corticosteroids are more likely to fail the therapy than patients without Raynaud's syndrome [26].

\section{CONCLUSIONS}

- Physiotherapeutic procedures slightly reduced the intensity of numbness in both day and night pain.

- Rehabilitation slightly improved the patient's functioning.

- The rehabilitation process helped to some extent in reducing discomfort, but did not enable the patient to return to work.

- In order to avoid aggravation of the problem, the patient should avoid hard, heavy work performed by the hands, and the patient should be regularly rehabilitated.

- During the next physiotherapeutic procedure, kinesitherapy and home exercises should be introduced.

\section{REFERENCES}

1. Oskouei AE, Talebi GA, Shakouri SK, et al. Effects of Neuromobilization Maneuver on Clinical and Electrophysiological Measures of Patients with Carpal Tunnel Syndrome. J Phys Ther Sci. 2014; 26: 1017-1022. https://doi.org/10.1589/jpts.26.1017

2. Białoszewski D. Fizjoterapia w ortopedii. Warsaw: PZWL Medical Publishing House; 2014.

3.Litak J, Grochowski C, Litak J, et al. Carpal Tunnel Syndrome treatment. J Educ Health Sport. 2017; 7(1): 141-146. http://dx.doi. org/10.5281/zenodo. 238710

4. Ciechanowska K, Łukowicz M. Wpływ sonoterapii na objawy zespołu cieśni kanału nadgarstka. J Educ Health Sport. 2017; 6: 612-616. http:// dx.doi.org/10.5281/zenodo.556846

5. Gniadek M, Trybus M. Zespół kanału nadgarstka - etiologia i leczenie. Prz Lek. 2016; 73(7): 521-530.

6. Georgiew F, Maciejczak A, Kania A, et al. Ocena przydatności krzywej I/T do diagnostyki zespołu cieśni nadgarstka. Acta Bio-Opt Inf Med Biomed Eng. 2013; 19(1): 40-48.

7. Gołąbek R, Majcher P. Zespół cieśni nadgarstka. Sport i Turystyka. Środkowoeuropejskie Czasopismo Naukowe 2018; 1(1): 123-140. https:// doi.org/10.16926/sit.2018.01.09

8. Nowak M, Jethon J. Zespół kanału nadgarstka - przegląd literatury i doświadczenia własne. Postępy Nauk Med. 2009; 9: 665-672.

9. Kowalska B, Płaza M. Rola ultrasonografii w diagnostyce neuropatii pourazowych oraz powikłań po operacjach nerwów obwodowych. Pediatr Med Rodz. 2014; 10(3): 265-269. 10.15557/PiMR.2014.0029

10. Wilk I. Zastosowanie masażu leczniczego w zespole cieśni kanału nadgarstka. Puls Uczelni. 2015; 9(1): 22-23.

11.Pasek J, Stanek A, Gębala K, et al. Nowe możliwości balneologii i medycyny fizykalnej u chorych z objawem Raynauda. Acta Balneol. 2015; 2(140): 136-140.

12. Kalużny K, Brola W, Fudala M. Zespół Raynauda w chorobach neurologicznych. Prz Med Uniw Rzesz Inst Leków. 2013; 4: 536-545.

13. Hartmann P, Mohokum M, Schlattmann P. The association of Raynaud's syndrome with carpal tunnel syndrome: a meta-analysis. Rheumatol Int. 2012;32: 569-574. https://doi.org/10.1007/s00296-011-2122-5

14. Wolny $\mathrm{T}$, Linek $\mathrm{P}$. Is manual therapy based on neurodynamic techniques effective in the treatment of carpal tunnel syndrome? A randomized controlled trial Clin. Rehabil. 2019; 33(5): 957-958. doi: $10.1177 / 0269215518822114$

15. Mohammadi S, Roostayi MM, Naimi SS, Baghban AA. The effects of cupping therapy as a new approach in the physiotherapeutic management of carpal tunnel syndrome. Physiother Res Int. 2019; 24(3): e1770. https://doi.org/10.1002/pri.1770

16. Zaralieva A, Georgiev GP, Karabinov V, Iliev A, Aleksiev A. Physical Therapy and Rehabilitation Approaches in Patients with Carpal Tunnel Syndrome. Cureus. 2020; 12(3): e7171. doi: 10.7759/cureus.7171

17. Wolny T, Saulicz E, Linek P, Shacklock M, Myśliwiec A. Efficacy of Manual Therapy Including Neurodynamic Techniques for the Treatment of Carpal Tunnel Syndrome: A Randomized Controlled Trial. J Manipulative Physiol Ther. 2017; 40(4): 263-272. doi: 10.1016/j. jmpt.2017.02.004

18. Genova A, Dix O, Saefan A, Thakur M, Hassan A. Carpal Tunnel Syndrome: A Review of Literature. Cureus. 2020; 12(3): e7333. doi: 10.7759/cureus.7333

19. Almasi-Doghaee M, Boostani R, Saeedi M, Ebrahimzadeh S, MoghadamAhmadi A, Saeedi-Borujeni MJ. Carpal compression, Phalen's and Tinel's test: Which one is more suitable for carpal tunnel syndrome? Iran J Neurol. 2016; 15(3): 173-174.

20. Kuo TT, Lee MR, Liao YY, Chen JP, Hsu YW, Yeh CK. Assessment of Median Nerve Mobility by Ultrasound Dynamic Imaging for Diagnosing Carpal Tunnel Syndrome. PLoS One. 2016; 11(1): e0147051. doi: 10.1371/journal.pone.0147051

21. Dakowicz A, Kuryliszyn-Moskal A, Latosiewicz R, et al. Ocena skuteczności dwóch różnych procedur terapeutycznych w leczeniu zachowawczym zespołu cieśni nadgarstka. Reumatolog. 2010; 48(4): 225-229.

22.Zwolińska J, Kwolek A. Skuteczność leczenia fizjoterapeutycznego pacjentów z zespołem cieśni kanału nadgarstka. Prz Med Uniw Rzesz Inst Leków. 2012; 4: 428-431.

23. Wilk I. Zastosowanie masażu leczniczego w zespole cieśni kanału nadgarstka. Puls Uczelni. 2015; (9)1: 22-23.

24. Kocjan J. Efficacy of neural mobilization and mid-carpal mobilization in the treatment of carpal tunnel syndrome. J Educ Health Sport. 2016; 6(6): 31-38

25. Ciechanowska K, Łukowicz $M$. Wpływ sonoterapii na objawy zespołu cieśni kanału nadgarstka. J Educ Health Sport. 2017; 6: 612-616.

26. Roh YH, Noh JH, Gong HS, Baek GH. Comparative study on the effectiveness of a corticosteroid injection for carpal tunnel syndrome in patients with and without Raynaud's phenomenon. Bone Joint J. 2017; 99-B(12): 1637-1642. doi: 10.1302/0301-620X.99B12.BJJ-2017-0371.R2 